\title{
Assessing the Islamic Bank Financing During Economic Recession: The Role of Stimulus Regulation POJK Number 11/POJK.03/2020
}

\author{
Ririn Riani ${ }^{1}$, Ries Wulandari ${ }^{2}$ \\ ${ }^{1}$ Fakultas Ekonomi dan Bisnis Syariah, Institut Agama Islam Tazkia, Bogor, Indonesia, ririnriani43@ gmail.com \\ ${ }^{2}$ Fakultas Ekonomi dan Bisnis Syariah, Institut Agama Islam Tazkia, Bogor, Indonesia, \\ rieswulandari@tazkia.ac.id
}

\begin{abstract}
This study examines the role of the POJK stimulus policy No. 11/POJK.03/2020 on the decision of financing in Indonesia Islamic banking. Furthermore, the study aims to be able to assess the financing behavior of Islamic banks. Accordingly, we design a quantitative approach with panel data analysis method. With case studies on 12 Islamic Commercial Banks with a time period from quarter 12017 to quarter 4-2020. We found that the total financing of Islamic banks experience significant changes after the period of economic recession that hit Indonesia. Then, the study found that the role of stimulus regulation has a positive and significant effect on the distribution of total bank financing. This shows that the stimulus regulation through financing relaxation or financing restructuring does not prevent banks from continuing to channel financing to the public. This study also found that Islamic banks do not behave pro-cyclicality behavior towards the business cycle.
\end{abstract}

Keywords: Banking, cycles, monetary, regulation.

\begin{abstract}
Abstrak. Penelitian ini mengkaji peran kebijakan stimulus POJK No. 11/POJK.03/2020 terhadap keputusan pembiayaan di perbankan syariah Indonesia. Selanjutnya, penelitian ini bertujuan untuk dapat menilai perilaku pembiayaan bank syariah. Oleh karena itu, kami merancang pendekatan kuantitatif dengan metode analisis data panel. Dengan studi kasus pada 12 Bank Umum Syariah dengan periode waktu dari triwulan 1-2017 sampai dengan triwulan 4-2020. Kami menemukan bahwa total pembiayaan bank syariah mengalami perubahan signifikan setelah periode resesi ekonomi yang melanda Indonesia. Kemudian, penelitian ini menemukan bahwa peran kebijakan stimulus berpengaruh positif dan signifikan terhadap penyaluran total pembiayaan bank. Hal ini menunjukkan bahwa kebijakan stimulus melalui relaksasi pembiayaan atau restrukturisasi pembiayaan tidak menghalangi perbankan syariah untuk terus menyalurkan pembiayaan kepada masyarakat. Penelitian ini juga menemukan bahwa bank syariah tidak berperilaku pro-siklus terhadap siklus bisnis.
\end{abstract}

Kata kunci: Moneter, perbankan, regulasi, siklus.

\section{INTRODUCTION}

\section{Background}

Various recessions that hit the global economy have been recorded in history, this is due to fluctuations or shocks which resulted in a decline in economic activity. The strong history of economic and financial crises shows that the banking sectors are fundamentally procyclical. Bakar (2014) stated that the instability of the financial sector which is the root of the problem of the recession is always closely related to the improper management of bank loan operations. This is reinforced by the empirical studies that prove the existence of a pro-cyclical relationship of interestbased bank lending operations to the business cycle (Ibrahim M. , 2016; Zulkhibri \& Sakti, 2018; Ascarya et al., 2016).

In this view, banking sector procyclicality is characterized as the result of a self-reinforcing interaction within the financial sector and between the banking sector's functioning and the real economy, resulting in unsustainable economic growth during upturns and deeper recessions during downturns (Clement, 2010). To put it another way, the banking sector has the potential to worsen cyclical oscillations, obstructing the effective allocation of resources in the economy and negatively 
impacting credit growth and financial stability. Pro-cyclicality that occurs in the banking sector which ultimately exacerbates fluctuations in the business cycle (Landau, 2009). Ascarya et al. (2016) states that pro-cyclicality behaviour in conventional banks creates bubbles, so that this condition has a negative impact on the economy. The size of the fluctuations that occur in the economic cycle is largely influenced by the credit mechanism (Saadaoui \& Hamza, 2020).

The occurrence of procyclicality can be marked when the economy develops exponentially through an increase in GDP, which then causes an increase in bank credit, both Islamic banks and conventional banks (Ascarya et al., 2016). In addition, the inflation rate can also affect the level of lending (Viphindrartin et al., 2020). According to Lin et al. (2016), rising inflation can weaken borrowers' ability to make loan payments as a result of reduced real income when wages are stiff (Lin et al, 2016). Ferri and Minsky (1992) documented that during periods of economic boom, banks and financial institutions were confident to maximize profits by expanding their loans excessively which eventually led to increased risk. This implies that financial system instability stems from procyclicality. Thus, it can exacerbate fluctuations that occur during the business cycle period (Asea and Blomberg, 1998). Market participants who fail to properly treat the time dimension of risk are a major cause of pro-cyclical lending behavior towards business cycle events in the economy. As a result, banks will be careful and minimize the possibility of more severe negative effects (Rajan, 1994).

However, the emergence of Islamic banking in the early 90s, attracted a lot of attention from academics and policy makers. The reason is, Islamic banks are considered more resistant to crisis shocks than conventional banks (Gamaginta and Rokhim, 2015; Hidayat and Abduh, 2012; Alzalabani and Nair, 2013; Saadaoui and Hamza, 2020; Bakar et al., 2012; Dridi and Hasan, 2010). Alzalabani and Nair (2013) stated that Islamic banking practices refer to the principles of Islamic law and its application which practically does not cause a crisis, and instead contributes positively to economic growth. Sharia principles strictly prohibit the interest-based system which contain riba, speculative transaction, and use the concept of profit-loss sharing (PLS) and trade-based (al-bay) transaction (Farooq \& Zaheer, 2015). According to Chapra (2011) the PLS concept makes Islamic banks more vigilant in lending activities, besides Islamic finance emphasizes the concepts of justice and fairness.

In several studies it was found that it turns out that Islamic banks have the same pro-cyclicality behaviour as interest-based banks, even Islamic banks are considered not to be more shock-resistant than their counterparts when the crisis occurs. This is evidenced by the research of Ascarya et al. (2016) which found that in Indonesia, Islamic banking together with conventional banks have the same pro-cyclical behaviour. Furthermore, Zaid et al. (2020) found that the behaviour of financing carried out by Islamic banks in Pakistan is considered to be more pro-cyclical than conventional banks. The same results are evidenced by research conducted by Soedarmono et al. (2017), Aysan and Ozturk (2018), Weil and Zins (2021).

Crisis cycle occurs continuously, currently the world is faced with the existence of a pandemic which has an impact on increasing the risk of a global economic recession. Indonesia is confirmed to be in a recession, due to contraction for two consecutive quarters. In the first quarter of 2020, Indonesia's economic growth itself was depressed to 2.97 percent. Then the worst condition was shown in the second quarter which recorded negative growth of up to $-5.32 \%$ (YoY). In the third quarter, the Indonesian economy increased slightly to $-3.49 \%$ (YoY), improving from the previous quarter. Then the latest data released by the Statistics Bureau (BPS) in the fourth quarter, Indonesia's growth was $2.19 \%$ year-on-year (YoY) (OJK, 2020).

So that during this period, there was a decrease in real gross domestic product, a slower money supply and the unemployment rate began to increase. This was exacerbated by the massive layoffs. Several business sectors have become disrupted, including the financial sector such as banking. Financial 
sector are always faced with systemic risk vulnerability. The existence of a pandemic has resulted in an increase in bank credit/financing risk, this is motivated by a decrease in the performance and capacity of the debtor in fulfilling credit or financing payment obligations. Rizwan et al. (2020) states that at least three reasons have led to an increase in systematic risk in banks during this pandemic. First, liquidity risk that occurs due to a slowing economy. Second, the loss of intermediary income, this increases the risk of an inevitable increase in NPL/NPF. Lastly, a sharp decline in the intermediation business could have a negative impact on the ability to finance the operations and funding costs of financial institutions.

This situation has finally forced the government to respond quickly through various policies, both to overcome problems in the short term and in the coming years (recovery). In order to maintain financial sector stability amidst the economic downturn due to the pandemic, the Financial Services Authority (OJK) issued the Financial Services Authority Regulation (POJK) Number 11/POJK.03/2020 concerning "National Economic Stimulus as a Countercyclical Policy on the Impact of the Spread of Pandemic Effect" on March 16, 2020. The issuance of countercyclical policies is implemented so that the Indonesian economic cycle is able to avoid extreme economic cycle movements, such as structural shocks or fluctuations in economic activity (Warijoyo and Solikin, 2003).

This POJK regulates relaxation of credit restructuring for debtors affected by the spread of Covid-19, both individuals, MSMEs, and corporations to mitigate the impact of slowing economic growth in Indonesia. These policies include three banking stimulus policies, five capital market stimulus policies, two non-bank financial industry (IKNB) policies, and one policy applicable to all financial services industries. With the release of POJK No.11/POJK.03/2020, it is hoped that banks, especially Islamic banks, can proactively identify their customers who are affected by the pandemic. This is because the performance and capacity of debtors during the pandemic is expected to decline, which in turn can increase credit risk. This credit risk can then potentially disrupt the performance of banks in Indonesia.

According to the Financial Services Authority Report, the bank credit restructuring policy until February 8, 2021 has reached Rp 987.48 trillion out of a total of 7.94 million debtors. Where the MSME sector reached 6.15 million debtors with a value of $\mathrm{Rp} 388.33$ trillion. Meanwhile, nonMSMEs reached 1.79 million debtors with a value of Rp 599.15 trillion (www.cnbcindonesia.com). The existence of restructuring is expected to be able to optimize banking performance, so that it can continue improvement efforts.

The relationship between the lending behaviour of banking institutions and the business cycle has become an important topic related to financial stability and banking regulation which has been widely researched by academics and policy makers. Many researchers have tested the stability of Islamic finance and tested the resilience of Islamic banking, especially in times of crisis. However, the results of these studies reveal that empirical studies are still not conclusive. Thus, this study was made to examine the impact of the pandemic that resulted in an economic recession and how Islamic banks responded to this situation. This paper aims to assess Islamic bank financing and the role of stimulus regulation during the recession that hit Indonesia due to the pandemic. And to examine the procyclicality behavior of Islamic banking financing on the business cycle, which is considered to be able to worsen economic conditions during a recession.

\section{Objective}

Based on the background and problem identification, this research has two objectives :

1. Assessing the Islamic bank financing during the period of economic recession

2. Analyze the impact of the stimulus regulation on Islamic commercial bank financing in Indonesia 
3. Confirm the behaviour of Islamic commercial bank financing during the business cycle of recession period.

The study will organize as follows. In section 1 the background and objectives of the research, section 2 discusses the theoretical background that supports research on Islamic banking financing during recession and will summarize various previous studies, while section 3 describes the data and research methods used in this study. Section 4, the core part, will present the analysis and discussion of these findings. The final section contains conclusions and some suggestions along with recommendations from the research findings and analysis.

\section{LITERATURE REVIEW}

\section{Background Theory}

\section{Overview of economic recession}

The economy is never separated from fluctuations, fluctuation in economic conditions in the long run is referred to as the business cycle. Business cycles occur in either months or years. The business cycle is characterized by four significant periods, namely periods of economic expansion, followed by periods of recession, contraction and economic revival (Layton and Banerji, 2003). However, one of the most talked about periods in the business cycle by researchers and policymakers alike is the period of recession.

A recession can be defined as a process of significant decline in aggregate economic activity, lasting more than a few months, which can be seen from the growth factor of real gross domestic product (GDP), real personal income, employment rate, and wholesale-retail sales (West, 1990). Mazurek and Mielcova (2013) defines a recession as a period of time in which a country's GDP decreases in a period of two consecutive quarters. In addition, other factors that can be used to measure the occurrence of a recession are employment, industrial production and real personal income. Furthermore, Shido-Ikwu (2017) mentioned that the recession is a phase of a negative economic cycle that occurs after two consecutive quarters featuring low output and investment, soaring unemployment, fluctuations in the foreign exchange market, liquidity, and a decrease in the availability of credit facilities.

The existence of economic fluctuations is not something new in the Islamic context. In the Quran and the hadiths, it has been explained about the existence of fluctuations in the economy, as stated in the Quran Surah Yusuf verses 46-49 as follows:

"Yusuf, a very trusted person! Explain to us about the seven fat cows which are eaten by seven thin cows, seven green (wheat) stalks and (seven stalks) that are dry. that I would return to those people, so that they might know." (46). He said, "For seven years you shall sow continuously, then what you reap leave it on the ear, except a little whereof you eat (47). Then thereafter there shall come upon you seven hard years, in which you shall devour all that you have reserved for them, except a little you keep in store (48). Then there shall come after that a year in which the people shall have rain and in which they shall press (fruit) (49). (Q.S Yusuf (12):46-49).

Furthermore, in the hadith which explains the occurrence of market disruptions at the time of Prophet Muhammad (saw). Based on the hadith narrated by Anas ibn Malik (ra), regarding price fluctuations.

"The people said: O Rosulullah, prices has shot up, so fix prices for us. Thereupon the Rosulullah (saw) said: "Verily, Allah (swt) determines the climate of economic affluence and gloom. I do not want to take any action to fix the prices. Because I do not want later in hereafter, any among you to demand for the return of your property and blood from me because of my tyranny (in fixing the prices). " in Sunan Abu Dawud.

Based on the verses of the Quran (Surah Yusuf; 12: 46-49) and the hadith quoted above, the existence of fluctuations in the economy is an event that is certain to occur, but is an undesirable phenomenon. The verses of the Quran and the hadith above inform us about the period of ups and downs in 60 
economic activity, in which it hints at the role of market mechanisms, as well as the mechanisms needed to manage and avoid economic fluctuations.

\section{The cause of procyclicality in lending behaviour}

Athanasoglou et al. (2014) explained that deviations that occur in the market are the biggest influence on the occurrence of bank procyclical behavior. This hypothesis argues that all available information is known by market participants so that it can be evaluated rationally, that is, it can detect the occurrence of temporary shocks and events that have long-term impacts. Thus, bank credit behavior must be counter-cyclical, because banks can observe and predict actual economic conditions. According to Geršl and Jakubík (2009) explained that the causes of procyclicality in banking are caused by various interrelated factors, such as information asymmetry, fluctuations in balance sheet quality, and excessive expectations of market participants. They also added that regulations related to financial institutions and accounting rules on financial institutions' balance sheets can also play an important role.

Furthermore, according to Diamond and Rajan (2005), states that asymmetric information is the main cause of procyclicality. This relates to the problem of adverse selection, which refers to misunderstandings. So the bank increases its lending during periods of economic upturn, and reduces it during periods of economic downturn. Therefore, it is necessary to have macroeconomic policies that can affect the economic cycle and the business cycle as an effort to anticipate financial risks. This is because state financial institutions, especially banks, will respond to every financial cycle, especially during an economic recession, by reducing creditors, known as credit rationing (Cowling, 2010).

Acording to Viphindrartin et al. (2020) the availability of credit itself is strongly influenced by bank management which adjusts to conditions when there are economic fluctuations. Bank management prefers risk-averse behavior when banks are faced with limitations in diversifying and distributing risk. As a result, almost all banks in the world tend to behave pro-cyclicality or reduce their lending during periods of economic downturn (Viphindrartin et al., 2020).

Athanasoglou et al. (2014) consider that in this case economic policies, and financial conditions as well as the bank's regulatory framework are factors that contribute to the pro-cyclicality of the banking industry. They emphasized that the existence of a capital requirement is the main cause of pro-cyclical behaviour, which will further reduce the supply of loans by banks. During a recession, when liquidity is limited in the real sector, the economy will certainly experience shocks. This is because many companies do not have alternative sources of funding. This pro-cyclicality behaviour of banks in real economic activities indicates that several actions must be taken to solve the business cycle. Banking regulations are believed to be one of the biggest causes of pro-cyclicality (Vozzella and Gabbi, 2020).

\section{Linkage between bank credit theory, economic growth and monetary policy}

The role of the bank cannot be separated from monetary policy. The banking system and the monetary mechanism play a very important role in the economic development of a nation (Thiagarajan, 2018). According to Warijoyo and Solikin (2003) monetary policy is part of government action, in this case the Central Bank, which is tasked with controlling the money supply in an economy. Furthermore, Mishkin (2006) explains that monetary policy is the duty of the central bank in influencing interest rates, the amount of credit, and the money supply, which ultimately achieve economic goals. The process of the influence of the monetary sector on the economic sector is called the monetary transmission mechanism (Fikri, 2018).

The theory of the monetary transmission mechanism can influence real activities through several channels, including the interest rate channel, the asset price channel, and the credit channel (Faraznejhad and Ramakrishan, 2019). One of the monetary transmission channels closely related to the role of banking intermediation is the credit channel. The credit channel explains the role of monetary policy on influencing banking in the real sectors of an economy (Shah et al., 2019). There 
are two sub-channels of credit channel theory, namely the balance sheet channel and the bank loan channel (Bernanke and Gertler, 1995). Whereas the balance sheet channel highlights the effect of shifts in monetary policy on borrowers' balance sheets, while the bank lending channel highlights the impact of monetary policy on loan supply through the banking structure.

Banks have a very important role in encouraging economic growth through an intermediary role to channel funds efficiently. According to Wulandari (2012), bank lending channels strengthen the role of banks in the economy, she documented that credit channel dominate to support economic growth in Indonesia. In the theory and model of bank lending channels, it is emphasized that savings are the main source of funds for investment and borrowing. According to Mishkin (2008) the financial sector, especially banking plays an important role in capital allocation, namely by facilitating the channeling of funds from surplus units to deficit units, thereby allowing more economic activity.

Furthermore, Goaied and Sassi (2010) explained that the banking intermediary function can ensure better mobilization of available savings and can sustain economic growth. Activities of channelling funds in the banking sector have a direct effect on consumption, both for personal consumption by households, business actors, and on the performance of the economy as a whole (Bakar, 2014). Banking plays its role by issuing bank deposit obligations that contribute to broad monetary aggregates. The Islamic banking industry has proven to be a contributor to the calculation of Indonesia's national income (Afandi and Amin, 2019).

\section{Banking regulation POJK 11/POJK.03/2020}

Banking regulation is a framework that functions to control the formation, operation and liquidation of banks in an economy (Alam, 2013). The Central Bank and the finance ministry generally have the authority to make a regulation, and control will be carried out through monitoring by a special banking supervisory authority. Currently in Indonesia, based on the OJK Law No. 21 of 2011 the supervisory and regulatory functions of banking are regulated and supervised by the OJK (Indonesian Financial Services Authority) (Mihajat, 2016).

The government's response as an effort to overcome a recession amid a deteriorating financial condition by issuing regulations on state financial arrangements (Kholiq and Rahmawati, 2020). The government issued an economic stimulus through OJK Regulation No.11/POJK.03/2020. Regarding the issuance of this stimulus regulation by the OJK in accordance with article 6 of Law Number 21 of 2011 which states that the duties of the OJK are the task of regulating as well as supervising financial service activities in the banking sector (Bidari and Nurviana, 2020). This was done to encourage optimization of the bank's function as an intermediary institution, maintained financial system stability and sound economic growth during the recession that hit Indonesia.

Regulation Number 11/POJK.03/2020 explains several things, namely: (1) General provisions; (2) Determination of asset quality, (3) Credit or financing restructuring, (4) Provision of new funds, (5) Reporting, (6) The validity period of providing the stimulus and (7) closing provisions (Kamilah, 2021). The main points of this regulation listed in the POJK Number 11/POJK.03/2020 are assessment of credit or financing quality based solely on the accuracy of principal or interest payments for credit or financing up to IDR 10 billion, determination of credit or financing quality to current after restructuring, and separation of quality assignments for new credit or financing.

Furthermore, this POJK regulates relaxation of credit restructuring for debtors affected by the spread of Covid-19, both individuals, MSMEs, and corporations. The restructuring scheme is left to each bank in accordance with the needs of the debtor and the bank's capacity, provided that it still observes the principle of prudence. Banks must assess the ability of debtors who are affected by the spread of COVID-19 to survive until the end of this POJK. This is because the said assessment will have an impact on the credit quality assessment or restructured financing. 


\section{Previous Study}

The research on the relationship of lending behavior between banking institutions and the business cycle have been summarized. Among them, research conducted by Bakar (2014). He analyzed the behaviour of 67 Islamic banks in 16 different countries using a data analysis panel. The variable used consists of several bank specific indicator such as: contingency reserve, loan loss provision, deposit growth, capital based growth, NPF growth and net profit growth, then the macroeconomic variables indicator such as: GDP, CPI and M2. His findings show that financing growth declines during economic growth whereas financing growth rates increase when the economy is weak. So that his research proves that Islamic banks have a behaviour that tends to be countercyclical to business cycle events.

Ibrahim (2016) examined the relative pro-cyclicality of 37 banks originating from Islamic banks and conventional banks in Malaysia, using a dynamic panel approach during the 2001-2013 period. The variables that used on the research consist of real asset, equity-asset ratio, deposit liabilities ratio, GDP and inflation rate. The results show that the pro-cyclicality of bank loans tends to limit procyclicality only to conventional loans. While the behaviour of Islamic bank financing was not detected pro-cyclicality behaviour during the study period.

Saadaoui and Hamza (2020) estimate the lending cyclicality in dual banking system using annual observations on a sample of 81 banks in the GCC countries in the period of 2005 until 2018 using dynamic panel methods. The study used the business cycle indicators as dependent variables consist of output gap and oil price gap. The finding of the study show that Islamic banks' lending is less procyclical than conventional banks or even behave countercyclical behaviour, giving support for the stability view of Islamic banking systems.

Furthermore, Viphindrartin et al. (2020) examines how Islamic banks can manage risk during the global economic crisis in 2008, which suppressed macroeconomic stability and the financial system in Indonesia. The study found that the GDP variable had no significant effect on Islamic bank financing in Indonesia. This supports the argument that the financing behavior of Islamic banks in Indonesia is not affected by the business cycle during the study period.

In contrast to the results of research conducted by Ascarya et al. (2016). Research comparing the behaviour of Islamic banks and conventional banks in Indonesia uses three quantitative methods, namely Ordinary Least Square (OLS), Error Correction Model (ECM), and Autoregressive Distributed Lag (ARDL). It was found that the two types of banks moved in line with the business cycle. However, it is interesting to explain that the pro-cyclicality that occurs in Islamic banks is known not to cause a credit bubble, and is considered to have a positive impact on long-term economic growth.

Aysan and Ozturk (2018) examined the lending behaviour in Turkish Islamic bank and conventional bank over the business cycle from 2005Q1 to 2012Q4 using panel-VAR methods. The variable used are GDP and the total credit and financing to estimate the cyclical behaviour. Also using some banks specific variables, namely total assets, share holders equity, NPL also NPF and ROA. Also consumer price index to measure inflation. The result show that Islamic banks are the same as conventional banks in terms of lending over the business cycles.

Furthermore, previous research related to the relationship between policies on Islamic bank financing. Based on research conducted by Nastiti and Kasri (2019) which discusses the role of banking policies in influencing the growth of Islamic bank financing in Indonesia for the period Q3 2015 to Q2 2017 using a data analysis panel. They try to assess the effectiveness of stimulus regulation in the form of a relaxation of the rules to mitigate the impact of slowing economic growth in Indonesia. The results show that the stimulus regulation issued in that period had a significant effect on the growth of Islamic bank financing. This is because the results of the study show conformity with the regulatory 
stimulus issued. Among them are the negative effect of capital requirements (CAR) on PYD and the positive impact of financing distributed to MSMEs, the collectability quality and banking investment on PYD.

Then, Amar et al. (2015) examined the impacts of macro-prudential policy on banks financing. They assessing the effectiveness of monetary policy transmission channels in Saudi Arabia with the presence of Islamic Banks during the 1990 -2013 period. The results show that Islamic bank financing was relatively effective in influencing non-oil and gas private output but was less effective in influencing consumer prices. The study also found that bank financing have a positive effect on improving economic activity.

Ozkan et al. (2014) examined the effect of regulation on banking sector performance in Turkey using three different bank performance measures, namely in terms of profitability, contribution of the banking sector in financing economic activities, and asset quality during the 1998-2009 period. The results show that banking sector regulations related to corporate governance on bank loans and asset quality have a significant positive effect on bank profitability. Moreover, the results show that all three regulatory measures have a positive effect on bank lending, which shows the contribution of Turkish banks to the financing of economic activity.

\section{Conceptual Framework}

In assessing Islamic bank financing during economic recession periods, the research framework that will be used in this study is based on the view of bank credit channels. Furthermore, the research will try to analyse the impact of stimulus regulation issued by the government. Does this policy affect the behaviour of Islamic commercial bank financing during the economic recession that hit Indonesia. The analytical model applied in this study is a combination of the models developed by Bakar (2014) and Nastiti and Kasri (2019). The research framework can be seen in the following figure:

\section{Bank Financing $=\mathbf{f}\{$ bank specific variables and macroeconomic variables $\}$}

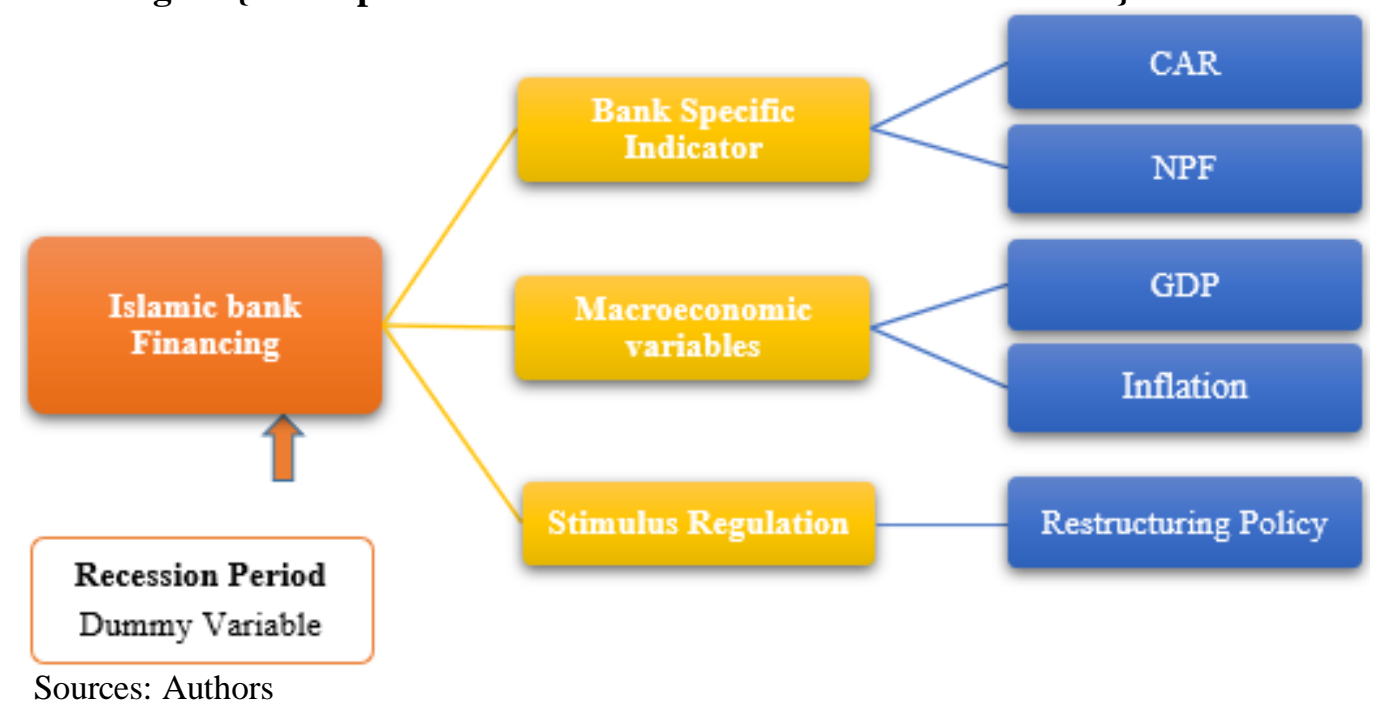

Figure 1 Research framework

Based on the literature in banking, the factors that are statistically proven to affect the ability of banks to carry out the intermediation function, namely the distribution of credit to the public are divided into two. First, internal factors are variables related to bank institutions including sources of funds and financing performance. To measure Islamic bank financing, internal factor which is the banking specific indicators are used as the main variables, namely CAR and NPF, Second, external factor based on the economic condition. The external factors are macroeconomic variables. Macroeconomic 
variables that are indicators of the business cycle will be measured based on gross domestic product variables and inflation. Third, the stimulus regulation which is used the restructuring policy, this restructuring policy was done to encourage optimization of the bank's function as an intermediary institution. Furthermore, dummy variables are included to measure the extent to which the Islamic Bank Financing before and after the economic recession.

\section{Research Hypothesis}

Hypotheses will be compiled based on literature and research framework. So that in this study there are two hypotheses to be tested. First, Analyzing the impact of the stimulus regulation on Islamic Commercial Bank financing in Indonesia. Second, examining the behaviour of Islamic Commercial Bank financing activities during the research period.

\section{First hypothesis}

H0 : The Islamic bank financing has no significant change during the economic recession $\mathrm{H} 1$ : The Islamic bank financing has significant change during the economic recession

\section{Second hypothesis}

$\mathrm{H} 0$ : The restructuring policy has no effect on the total Financing of Islamic Commercial Bank in Indonesia

H1 : The restructuring policy affects on the total Financing of Islamic Commercial Bank in Indonesia

\section{Third hypothesis}

H0 : Islamic Commercial Bank financing activities behave no pro-cyclicality behaviour to the business cycle

H1 : Islamic Commercial Bank financing activities behave procyclicality behaviour to the business cycle.

\section{METHOD}

In assessing Islamic bank financing during economic recession periods, the research framework that will be used in this study is based on the view of bank credit channels. Furthermore, the research will try to analyse the impact of stimulus regulation issued by the government. Does this policy affect the behaviour of Islamic commercial bank financing during the economic recession that hit Indonesia. The analytical model applied in this study is a combination of the models developed by Bakar (2014) and Nastiti and Kasri (2019). The research framework can be seen in the following figure:

\section{Data}

This research uses quarterly data, from the $1^{\text {st }}$ quarter of $2017-1^{\text {st }}$ quarter of 2021 . The period of study were selected based on the completeness of available data. The samples that will be tested in this study are 12 commercial banks in Indonesia, including: PT. Bank BTPN Syariah, PT. Maybank Syariah, PT. Bank Muamalat Indonesia, PT. Victoria Syariah Bank, PT. Bank BRI Syariah, PT. Bank Jabar Banten Syariah, PT. Bank BNI Syariah, PT. Bank Syariah Mandiri, PT. Bank Mega Syariah, PT. Panin Syariah Bank, PT. Bukopin Islamic Bank, and PT. BCA Syariah.

Data relating to banking indicators are obtained from the quarterly financial reports of each bank. Then, inflation data are taken from the Bank Indonesia website. Meanwhile, gross domestic product data is obtained from Statistic Indonesia website. 
Table 1 Operational definition of variable

\begin{tabular}{|c|c|c|}
\hline Variable & Definition & Symbol \\
\hline CAR & $\begin{array}{l}\text { The bank's capital adequacy ratio, which is measured based on a } \\
\text { comparison between total capital and risk-weighted assets } \\
\text { (RWA). The formula as follows: } \\
\text { CAR }=\frac{\text { CAPITAL }}{\text { WEIGHTED RISK ASSET }} \times 100 \%\end{array}$ & Percentage \\
\hline NPF & $\begin{array}{l}\text { Non-performing financing, which consists of loans classified as } \\
\text { Substandard, Doubtful and Loss. The formula as follows: } \\
\text { NPF }=\frac{\text { NON - PERFORMING FINANCING }}{\text { TOTAL FINANCING }} \times 100 \%\end{array}$ & Percentage \\
\hline RF & $\begin{array}{l}\text { Restructuring Financing means changes in credit terms relating } \\
\text { to actions for additional bank funds and or conversion of all or } \\
\text { part of arrears of interest into new loan principal and or } \\
\text { conversion of all or part of credit into participation in the } \\
\text { company, which may be accompanied by rescheduling and or } \\
\text { restructuring requirements }\end{array}$ & $\begin{array}{l}\text { Nominal } \\
\text { on IDR }\end{array}$ \\
\hline GDP & $\begin{array}{l}\text { According to expenditure approach, GDP is the amount of the } \\
\text { value of goods and services produced in the certain period of } \\
\text { time to be used as final consumption by households, non-profit } \\
\text { institutions serving households and the government plus } \\
\text { investment, as well as exports net. The formula as follows: } \\
G D P=C+I+G+N X\end{array}$ & $\begin{array}{l}\text { Nominal } \\
\text { on IDR }\end{array}$ \\
\hline INF & $\begin{array}{l}\text { An increase in the price of goods as measured by changes in the } \\
\text { consumer index, which reflects changes in prices for goods and } \\
\text { services needed by the wider community. } \\
\text { The Consumer Price Index is an indicator used by the } \\
\text { government to measure the inflation in Indonesia. The formula } \\
\text { as follows: } \\
C P I=\frac{C P I n-C P I 0}{C P I 0} \times 100 \%\end{array}$ & Percentage \\
\hline $\begin{array}{c}\text { Dummy } \\
\text { Regulation }\end{array}$ & $\begin{array}{l}\text { In this study the dummy variable is used to explain the period } \\
\text { before and after economic recession hit Indonesia due to the } \\
\text { pandemic. The use of dummy variables is expected to capture } \\
\text { the condition of Islamic bank financing before and after } \\
\text { economic recession period. The following symbols are used: } \\
\mathrm{D}=1 \text { after the economic recession period (start from the first } \\
\text { quarter of } 2020 \text { ). } \\
\mathrm{D}=0 \text { before the economic recession period (others). }\end{array}$ & $\begin{array}{c}\text { Dummy } 0 \\
\text { and } 1\end{array}$ \\
\hline
\end{tabular}

This section consists of explanation about the data used in this study and why, with respect to the requirement of the method(s) used.

\section{Model Development}

Specifically, the research model is presented as follows:

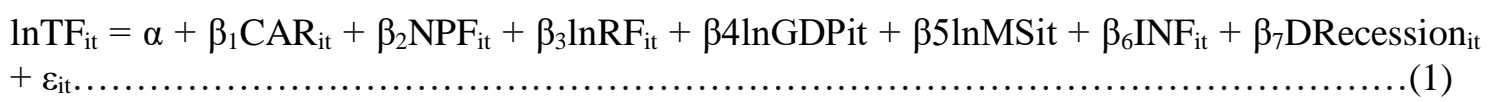

Where, $\beta_{1}<0, \beta_{2}<0, \beta_{3}>0, \beta_{4}<0, \beta_{5}>0, \beta_{6}<0, \beta_{7}>0$ 
$\mathrm{TF}_{\mathrm{it}}$ : Total Financing for bank $i$ at time $t$

$\mathrm{CAR}_{\mathrm{it}}$ : Capital to Adequacy Ratio for bank $i$ at time $t$

$\mathrm{NPF}_{\text {it }}$ : Non-performing Financing for bank $i$ at time $t$

$\mathrm{RF}_{\mathrm{it}}$ : Restructuring Financing for bank $i$ at time $t$

$\mathrm{GDP}_{\mathrm{it}}$ : Gross Domestic Product for bank $i$ at time $t$

$\mathrm{MS}_{\text {it }}$ : Money Supply (M2) for bank $i$ at time $t$

$\mathrm{INF}_{\mathrm{it}}$ : Inflation for bank $i$ at time $t$

DRecession $_{\text {it }}: 1$ (after the economic recession period) 0 (before the economic recession period) for bank $i$ at time $t$

$\varepsilon_{\text {it: }}$ Error in the model

$\alpha:$ intercept

ln : Natural logarithm

\section{Method}

We develop panel data estimation following Baltagi (2005). Based on panel data estimation, there are three alternative models of panel data analysis that can be used to estimate the behaviour of Islamic bank financing, namely the pooled least squares model or often referred to as the common effect model, the fixed effect model and the random effect model.

Furthermore, to determine the best model in estimating panel data regression. Several test techniques are used, namely the Chow test to choose between common effect or fixed effect models. Second, the Hausman test is used to choose between the best fixed effect or random effect model in estimating panel data regression. Third, the Lagrange Multiplier test to choose between common effect or random effect model.

After the model is selected, the next step is to test the hypothesis. Hypothesis testing can be measured by looking at the value of the F statistic, the value of the $\mathrm{t}$ statistic, and the value of the coefficient of determination. The $\mathrm{F}$ test was conducted to see whether the independent variables used in the study were able to explain changes in the dependent variable. In other words, the F-statistic test is used to test whether the use of the model is appropriate and reliable. Furthermore, the value of t-statistic is used to see the effect of each independent variable on the dependent variable. Finally, by looking at the value of the coefficient of determination $(\mathrm{R})$ which aims to assess how far the regression model used is able to explain the dependent variable.

\section{RESULTS AND DISCUSSION}

\section{Results}

Table 2 Descriptive statistics

\begin{tabular}{cccccc}
\hline Variable & Mean & Median & Max & Min & Std. Dev \\
\hline TF & $19,536,081$ & $6,400,508$ & $95,114,699$ & 54.00000 & $24,107,549$ \\
CAR & 0.343207 & 0.201300 & 3.464300 & 0.101600 & 0.502233 \\
NPF & 0.026321 & 0.023200 & 0.084900 & 0.000000 & 0.017960 \\
RF & $2,593,734$ & $871,770.5$ & $16,815,209$ & 0.000000 & $4,031,917$ \\
GDP & $2,625,641$ & $2,632,048$ & $2,818,722$ & $2,378,146$ & $1,167,461$ \\
INF & 0.007138 & 0.008350 & 0.016700 & -0.000200 & 0.004746 \\
Dummy & 0.250000 & 0.000000 & 1.000000 & 0.000000 & 0.434145 \\
\hline
\end{tabular}

Table 2 shows descriptive statistics of total Islamic banking financing, bank-specific variables, namely the capital adequacy ratio (CAR), credit risk ratio (NPF), and total financing restructuring expressed in natural logarithms as well as macroeconomic variables as procyclical indicators proxied by GDP and inflation, and a dummy variable that shows the period before and after the economic

AL-MUZARA'AH Special Issue 2022 
recession. The following facts were found regarding the Islamic banking industry in Indonesia that were arrested: The total financing disbursed has a number that is quite varied, indicating that there are quite significant differences between each bank in distributing its financing to the public. Furthermore, the CAR value shows a number that is still relatively safe. Meanwhile, the NPF variable found a fairly large value, indicating that Islamic banking at certain banks is still experiencing significant bad credit problems. The financing restructuring variable indicates that not all banks implement this program at their discretion. Furthermore, on macroeconomic variables, it can be seen that the Indonesian economy in the study period experienced fluctuations, especially after the pandemic that caused an economic recession.

\section{Model Estimation Result}

Table 3 Model estimation result

\begin{tabular}{cccc}
\hline Variables & PLS & FEM & REM \\
\hline CONSTANT & -6.845534 & 4.677654 & 3.474057 \\
& $(0.8327)$ & $(0.7940)$ & $(0.8458)$ \\
CAR & $-3.204152^{* * *}$ & $-1.708828^{* * *}$ & $-1.829341^{* * *}$ \\
& $(0.0000)$ & $(0.0000)$ & $(0.0000)$ \\
NPF & -9.095454 & -5.964344 & -5.154117 \\
& $(0.1041)$ & $(0.3091)$ & $(0.3618)$ \\
InRF & $0.129791 * * *$ & $0.189069^{* * *}$ & $0.181082 * * *$ \\
& $(0.0000)$ & $(0.0000)$ & $(0.0000)$ \\
InGDP & 1.520871 & 0.653202 & 0.742379 \\
& $(0.4877)$ & $(0.5888)$ & $(0.5380)$ \\
INF & -13.10066 & -6.942856 & -7.443227 \\
& $(0.5217)$ & $(0.5320)$ & $(0.5024)$ \\
DUMMY & -0.293772 & $-0.456326 * * *$ & $-0.441310 * * *$ \\
& $(.0 .1811)$ & $(0.0003)$ & $(0.0004)$
\end{tabular}

Chow Test

$41.891873^{* * *}$

(0.000)

Hausman Test

4.410782

(0.6213)

LM Test

Notes:

*** significant at $1 \%$ significance level, ** significant at $5 \%$ significance level, *significant at $10 \%$ significance level

Sources: Appendix

Table 3 shows the model estimation through 3 panel data model approaches, namely Pooled Least Square, Fixed Effect Model and Random Effect Model. To choose the best model in this study, several tests were carried out. First, the results of the Chow test show that the F-statistic value is 41.891873 and the Chi-square probability value is $(0.0000)$ or below 5 percent $(0.0000<0.5)$. Thus, the selected panel model is the Fixed Effect Model (FEM). Second, the Hausman test results show that the probability of F-statistics is $(0.6213)$ or greater than 5 percent $(0.6213>0.05)$. So, the selected panel model is the Random Effect Model. Next, the third test is the Lagrange Multiplier test. The results show that the F-statistic value is 582.0021 with the probability value of the F-statistic in the Breusch-Pagan test is 0.000 or below 5 percent $(0.000<0.05)$. Therefore, it can be concluded that the best estimation model in this study is the Random Effect Model (REM). 


\section{Hypothesis Testing}

Dependent Variable: $\operatorname{lnTF}$

Table 4 Output of random effect model

Method: Panel EGLS (Cross-section random effects)

Sample: 2017Q1 2021Q1

Periods included: 17; Cross-sections included: 12

Total panel (balanced) observations: 204

Swamy and Arora estimator of component variances

\begin{tabular}{cclcc}
\hline Variable & Coefficient & Std. Error & t-Statistic & Prob. \\
\hline C & 3.474057 & 17.83511 & 0.194788 & 0.8458 \\
LN_FR & 0.181082 & 0.032069 & 5.646621 & 0.0000 \\
CAR & -1.829341 & 0.241466 & -7.575968 & 0.0000 \\
NPF & -5.154117 & 5.638321 & -0.914123 & 0.3618 \\
LGDP & 0.742379 & 1.203101 & 0.617055 & 0.5380 \\
INF & -7.443227 & 11.07640 & -0.671990 & 0.5024 \\
DUMMY & -0.441310 & 0.122957 & -3.589132 & 0.0004 \\
C & 3.474057 & 17.83511 & 0.194788 & 0.8458 \\
& & & & \\
Root MSE & 0.657381 & R-squared & 0.592958 \\
Mean dependent var & 2.237929 & Adjusted R-squared & 0.579756 \\
S.D. dependent var & 1.095191 & S.E. of regression & 0.656692 \\
Sum squared resid & 84.52380 & F-statistic & 52.65933 \\
Durbin-Watson stat & 1.512349 & Prob(F-statistic) & 0.000000 \\
\hline N & & & & \\
\hline
\end{tabular}

Notes: $* * *$ significant at $1 \%$ significance level, $* *$ significant at $5 \%$ significance level, $*$ significant at $10 \%$ significance level

Sources : Appendix

\section{Robustness Test}

\section{Simultaneous significance test}

Because the F-statistic probability value is 0.00 or below 5 percent $(0.00<0.05)$, so the variables CAR, NPF, lnRF, lnGDP, INF and dummy variable simultaneously affect the lnTF variable. It conclude that the use of the model in this research is appropriate and reliable.

\section{Partial significance test}

From the table above, it can be concluded that CAR variable has a coefficient value of -1.829341 with a probability value of 0.0000 or below 5 percent $(0.000<0.05)$, this shows that the CAR variable has a negative and significant relationship with Islamic bank financing. The NPF variable has a coefficient value of -5.154117 with a probability value of 0.3618 or greater than 5 percent $(0.000<$ 0.05), this shows that the NPF variable has no significant relationship with Islamic bank financing. The $\operatorname{lnRF}$ variable has a coefficient value of 0.181082 with a probability value of 0.0000 or below 5 percent $(0.000<0.05)$, this shows that the $\mathrm{lnRF}$ variable has a positive and significant relationship with Islamic bank financing.

In contrast to the macroeconomic variables which show no significant effects on Islamic bank financing. The GDP variable has a coefficient value of 0.742379 with a probability value of 0.5380 or greater than 5 percent $(0.000<0.05)$, then the INF variable has a coefficient value of -7.443227 with a probability value of 0.5024 or greater than 5 percent $(0.000<0.05)$, indicating that the macroeconomic variable has no significant relationship with Islamic bank financing. Furthermore, the dummy variable has a coefficient value of -0.441310 with a probability value of 0.0004 or lower than $5 \%(0.0004<0.05)$ indicating that the economic recession has an impact on the disbursement of Islamic bank financing. 


\section{Coefficient of determination}

The adjusted R-square value of $0.57(57 \%)$ means that the variable $\mathrm{Y}$ or $\operatorname{lnTF}$ can be explained by variables CAR, NPF, lnRF, lnGDP, INF and dummy by 57\% while the remaining $43 \%$ is explained by variables outside the model.

\section{Discussion}

Regression results that have been carried out previously show that the dummy variable which states the period of economic recession has a significant effect on the total financing of Islamic banks. This shows that there is a significant change in total financing in Indonesia in the period before and after the economic recession hit Indonesia due to the pandemic. Several banks were found to have begun to limit the distribution of financing to the public in the midst of a pandemic. See the table below:

Table 5 Total financing before and after the economic recession

\begin{tabular}{cccccc}
\hline Variable & Mean & Median & Max & Min & Std. Dev \\
\hline Before & & & & & \\
Recession & 19220139 & 6089807 & 93447006 & 9432.000 & 23734999 \\
TF & 0.314459 & 0.198050 & 2.418400 & 0.101600 & 0.398386 \\
CAR & 0.026479 & 0.024400 & 0.084900 & 0.000000 & 0.017882 \\
NPF & 2087616 & 779105.0 & 15128182 & 0.000000 & 3596299 \\
RF & & & & & \\
After & 20483907 & 7510276 & 95114699 & 54.00000 & 25427262 \\
Recession & 0.429452 & 0.206300 & 3.464300 & 0.121200 & 0.729407 \\
TF & 0.025848 & 0.020900 & 0.058900 & 0.000000 & 0.018374 \\
CAR & 4112088 & 2211990 & 16815209 & 0.000000 & 4855237 \\
NPF & & & & & \\
RF & & & & & \\
\hline
\end{tabular}

Sources: Appendix

Availability of credit is strongly influenced by bank management which adjusts to economic conditions (Viphindrartin et al., 2020). When banking is disturbed by limitations in diversifying and distributing risk, bank management will choose risk-averse behavior. This is because when banks are faced with limited capital, banks will face various risks such as non-performing loans, liquidity risks, and other risks (İncekara \& Çetinkaya, 2019). The increase in non-performing loans shows signs of a decline in the performance of the banking sector and a decline in the quality of the credit portfolio. So that the function of banking intermediation as a channel of funds is also disrupted. As a result, there are limitations in increasing bank lending as pandemic affects borrowers' ability to repay loans.

Then, the stimulus regulation issued by the OJK in the form of a countercyclical policy regarding the impact of the spread of the COVID-19 pandemic aims to maintain financial system stability, namely by encouraging banking performance, especially the intermediation function. This stimulus regulation Number 11/POJK.03/2020 specifically provides a stimulus for Islamic Bank financing with a certain amount and restructured financing to affected debtors including micro, small and medium business debtors.

In this study, the role of stimulus regulation is measured through the total variable of financing restructuring, to see the extent to which the stimulus policy affects the distribution of total Islamic bank financing. In an effort to assess whether Islamic banks are more resistant to shocks due to economic fluctuations that occurred during the pandemic. The Financial Services Authority itself believes that this policy is able to ease the burden on debtors during the Covid-19 pandemic, as an effort to continue to help business continuity. This step is also expected to assist banks in managing their financial performance, especially in terms of mitigating credit risk (Christian et al., 2021). 
The results are as expected by policy makers, that the financing restructuring variable has a positive and significant effect on the distribution of total bank financing. This shows that the stimulus policy through financing relaxation or financing restructuring does not prevent banks from continuing to channel financing to the public. Banks can continue their duties as intermediary institutions that channel funds to the public. Of course, this policy is a good signal for banks amid conditions of economic uncertainty, provided that banks still have to be more selective in channeling their funds.

In this study it was found that the CAR variable had a significant negative effect on Islamic bank financing. CAR is the ratio that represented the ability of banks to provide funds to overcome various risks. In principle, higher capital requirements will cause banks to manage risk-weighted assets to meet these requirements. This is interesting because a higher capital ratio often means more funds available for loans. According to Aysan and Ozturk (2018), a negative coefficient between capital and financing indicates the growth of financing channeled by banks. Martynova (2015) documented that when the economy declines, banks will take a risk-taking channel by holding less capital. The findings in this study are also in line with research conducted by Karim et al. (2014), Yuanyan and Tressel (2017) and Nastiti and Kasri (2019).

Non-Performing Financing Ratio (NPF) is a ratio used to evaluate the financial performance of Islamic banks (Murdiyanto, 2021). In distributing financing, Islamic banks are faced with financing risks. In this study, it was found that the NPF variable had a negative effect on Islamic bank financing but not significant. These results indicate that in times of economis slow downs, financial institutions will limit the distribution of financing (Gertler \& Kiyotaki, 2010). According to Syamlam and Jannah (2019), the higher the NPF, the more selective banks will be in distributing credit to minimize risk (Pratama, 2010; Murdiyanto, 2021).

Furthermore, it was found that all macroeconomic variables did not have a significant effect on Islamic bank financing in Indonesia. This evidence show that the behavior of financing disbursement in Indonesia during the research period does not depend on the business cycle conditions. The nonsignificance of macroeconomic variables, namely gross domestic product, and inflation in influencing the growth of Islamic bank financing indicates that Islamic bank financing decisions are not bound by expansion and contraction in the market (Bakar, 2014).

This finding supports the argument that the financing behavior of Islamic banks in Indonesia are not pro-cyclical, which is free from speculative behavior when there are fluctuations in the economic environment. The results of this study are in line with research conducted by Beck et al. (2013), Bakar (2014), Ibrahim (2016), Zulkhibri and Sakti (2018), and Viphindrartin et al. (2020). Thus, the financing behavior of Islamic banks is more influenced by other factors, especially institutional factors such as capital regulation, financing performance and intermediation function which have a significant relationship. Where the result supports the opinion of Kasri and Azzahra (2020) who documented that the stability of Islamic bank is more influenced by the bank internal factors than macroeconomic variables. According to Ahmed (2013) the resilience of Islamic banking is more influenced by its own internal dynamics factors, in contrast to the counterparts which integrate with macroeconomic variables. Considering that the share and the total asset of Islamic banking are still lower than conventional banking.

\section{CONCLUSION}

\section{Conclusion}

This study aims to assess the Islamic bank financing in the time of economic recession. The result show that there is a significant change in total financing in Indonesia in the period before and after the economic recession hit Indonesia. The function of banking intermediation as a channel of funds is 
disrupted, because there are limitations in increasing bank loans due to the disruption of the borrower's ability to repay loans amidst the economic downturn.

This study also discusses the role of the stimulus regulation in influencing the total financing of Islamic banks in Indonesia, the role of stimulus regulation is measured through the total variable of financing restructuring. The results are as expected by policy makers, that the financing restructuring variable has a positive and significant effect on the distribution of total bank financing. This shows that the stimulus regulation through financing relaxation or financing restructuring does not prevent banks from continuing to channel financing to the public.

Furthermore, this study found that during the study period, Islamic banks did not show pro-cyclical behavior towards the business cycle that could exacerbate fluctuations. This is indicated by the insignificant GDP variable in influencing financing during the study period. Thus, this study supports the argument that Islamic banks are more resistant to shocks caused by economic fluctuations.

\section{Recommendation}

In the study, it was found that the stimulus regulation has been quite effective in accelerating Islamic banking financing as an effort to optimize the banking intermediation function in maintaining financial system stability and supporting economic growth. However, the performance of banks in mitigating risks must continue to be carried out. So to prevent the same possibility in the future, regulations related to internal sharia banking must be paid more attention to by regulators. In addition, other alternative instruments must be prepared for use in the future, considering that the economy will continue to fluctuate.

Furthermore, for further research, other internal banking factors can be added, with a longer period of time. Then, research comparing sharia and conventional institutions is also expected to be able to measure the performance of the two types of banking. Research using samples from several countries that implement a dual banking system is also expected to be researched.

\section{REFERENCES}

Afandi, M. A. \& Amin, M. (2019). Islamic bank financing and its effects on economic growth: A cross province analysis. Jurnal Ilmu Ekonomi, 8(2), 243-250.

Ahmed, H. (2013). Islamic Banking and Financial Crisis: Reputation, Stability and Risks. Edinburgh (UK), Edinburgh University Press.

Alam, N. (2013). Impact of banking regulation on risk and efficiency in Islamic banking. Journal of Financial Reporting and Accounting, 11(1), 29-50.

Alzalabani, A. \& Nair, R. D. (2013). Financial recession, credit crunch and Islamic banks: A case study of Al Rajhi Bank in the Kingdom of Saudi Arabia. Journal of Economics and Business, 16(1), 15-36.

Amar, A. B., Hachicha, N. \& Saadallah, R. (2015). The effectiveness of monetary policy transmission channels in the presence of Islamic banks: the case of Saudi Arabia. International Journal of Business, 20(3), 1083-4346.

Ascarya, Rahmawati, S. \& Karim, A. A. (2016). Testing of the procyclicality of Islamic and conventional banks in Indonesia. Macroprudential Regulation and Policy for Islamic Financial Industry, 133-152.

Asea, P. K. \& Blomberg, B. (1998). Lending cycles. Journal of Econometrics, 83(1-2), 89-128.

Athanasoglou, P., Daniilidis, I. \& Delis, M. (2014). Bank procyclicality and output: Issues and policies. Journal of Economics and Business, 72, 58-83.

Aysan, A. F. \& Ozturk, H. (2018). Does Islamic banking offer a natural hedge for business cycles? Evidence from a dual banking system. Journal of Financial Stability, 36, 22-38.

Bakar, M. A. (2014). The Cyclical Behaviour of Islamic Bank Financing. (Doctoral Dissertation, 
University of Malaysia, Kuala Lumpur, Malaysia).

Bakar, M. A., Kader, R. A., Zakaria, R., Wahid, H., \& Harun, M. (2012). Islamic bank financing behaviour: A preilinary study. International Conference on Innovation and Technology for Sustainable Built Environment, 803-810.

Baltagi, B. H. (2005). Econometric Analysis of Panel Data. New Jersey (UK), John Wiley \& Sons.

Beck, T., Demirguc-Kunt, A. \& Merrouche, O. (2013). Islamic vs. conventional banking: Business model, efficiency and stability. Journal of Banking and Finance, 37(2).

Bernanke, B. S. \& Gertler, M. (1995). Inside the black box: The credit channel of monetary policy transmission. Journal of Economic Perspectives, 9(4), 27-48.

Bidari, A. S. \& Nurviana, R. (2020). Stimulus ekonomi sektor perbankan dalam menghadapi pandemi coronavirus disease 2019 di Indonesia. Jurnal Ilmu Hukum, 4(1), 297-305.

Chapra, M. U. (2011). The global financial crisis: Some suggestions for reform of the global financial architecture in the light of Islamic finance. Thunderbird International Business Review, 53(5), 565-579.

Christian, M., Dewi, D., Rembulan, G. D., Indriyarti, E. R., Wibowo, S., \& Yuniarto, Y. (2021). Business Performance Determinants of Salted Fish Distribution in Kapuk During the COVID19. Journal of Distribution Science, 19(6), 29-39.

Clement, P. (2010). The term 'macroprudential': Origins and evolution. BIS Quarterly Review, March.

Cowling, M. (2010). Economic Evaluation of the Small Firms Loan Guarantee (SFLG) Scheme. London (UK), Department for Business Innovation \& Skills.

Diamond, D. W. \& Rajan, R. G. (2005). Liquidity shortages and banking crises. The Journal of Finance, 60(2), 614-647.

Dridi, J. \& Hasan, M. (2010). Have Islamic banks been impacted differently than conventional banks during the recent global crisis?. International Monetary Fund, 10, 201.

Faraznejhad, M., \& Ramakrishan, S. (2019). Effectiveness of credit channel of monetary policy transmission mechanism on commercial banks in Malaysia. International Journal of Recent Technology and Engineering (IJRTE), 8(1), 913-926.

Farooq, M., \& Zaheer, S. (2015). Are Islamic banks more resilient during financial panics? Pacific Economic Review, 20(1), 101-124.

Ferri, P. \& Minsky, H. P. (1992). Market processes and thwarting systems. Structural Change and Economic Dynamics, 3(1), 79-91.

Fikri, R. J. (2018). Monetary transmission mechanism under dual financial system in Indonesia: Credit-financing channel. Journal of Islamic Monetary Economics and Finance, 4(2), 251-278.

Gamaginta \& Rokhim, R. (2015). The stability comparison between Islamic banks and conventional banks: Evidence from Indonesia. Financial Stability and Risk Management in Islamic Financial Institutions, 104-120.

Geršl, A. \& Jakubík, P. (2009). Procyclicality of the financial system and simulation of the feedback effect. Financial Stability Report, 110-119.

Gertler, M. \& Kiyotaki, N. (2010). Financial intermediation and credit policy in business cycle analysis. Handbook of Monetary Economics, 3, 547-599.

Goaied, M., \& Sassi, S. (2010). Financial development and economic growth in the MENA region: What about Islamic banking development. Institut des Hautes Etudes Commerciales, Carthage, $1-23$.

Hidayat, S. E. \& Abduh, M. (2012). Does financial crisis give impacts on Bahrain Islamic Banking performance: A panel regression analysis. International Journal of Economics and Finance, $4(7), 79-87$.

Ibrahim, M. (2016). Business cycle and bank lending procyclicality in a dual banking system. Economic Modelling, 55, 127-134.

İncekara, A. \& Çetinkaya, H. (2019). Liquidity risk management: A comparative analysis of panel data between Islamic and conventional banking in Turkey. Procedia Computer Science, 158, 955-963.

Kamilah, A. (2021). Countercyclical debtors policy as a form of protection againts banking due to the

AL-MUZARA'AH Special Issue 2022 
impact of coronavirus desease 2019. International Conference on Education of Suryakancana (IConnects Proceedings), 440-445.

Karim, M. A., Hassan, M. K., Hassan, T. \& Mohamad, S. (2014). Capital adequacy and lending and deposit behaviors of conventional and Islamic banks. Pacific-Basin Finance Journal, 28, 58-75.

Kasri, R. A. \& Azzahra, C. (2020). Do Islamic banks more stable than conventional banks? Evidence from Indonesia. Jurnal Ekonomi \& Keuangan Islam, 6(2), 149-164.

Kholiq, A. \& Rahmawati, R. (2020). Dampak implementasi restrukturisasi pembiayaan terhadap likuiditas bank syariah pada situasi pandemi covid-19. Journal of Islamic Economic and Business, 3(2), 282-316.

Landau, J. P. (2009). Complexity and the financial crisis. Banque de France Speech, 2-3.

Layton, A. P. \& Banerji, A. (2003). What is a recession?: A reprise. Applied Economics, 35, 17891797.

Lin, H. Y., Farhani, N. H., \& Koo, M. (2016). The impact of macroeconomic factors on credit risk in conventional banks and Islamic banks: Evidence from Indonesia. International Journal of Financial Research, 7(4), 105-116.

Martynova, N. (2015). Effect of bank capital requirements on economic growth: A survey. De Nederlandsche Bank Working Paper No. 467.

Mazurek, J. \& Mielcova, E. (2013). The evaluation of economic recession magnitude: Introduction and application. Prague Economic Papers, 2 (1), 182-205.

Mihajat, M. S. (2016). Macro-prudential supervision in the Indonesia financial services authority (OJK) and the role of sharia board: A proposed framework. Journal of Islamic Banking and Finance, 72-85.

Mishkin, F. S. (2006). Monetary Policy Strategy: How Did We Get Here?. Cambridge (US), National Bureau of Economic Research.

Mishkin, F. S. (2008). How should we respond to asset price bubbles. Financial Stability Review, 12(1), 65-74.

Murdiyanto, A. (2021). Faktor-faktor yang berpengaruh dalam penentuan penyaluran kredit perbankan. In Conference in Business, Accounting, And Management (CBAM), 1(1), 61-75.

Nastiti, N. D., \& Kasri, R. A. (2019). The role of banking regulation in the development of Islamic Banking financing in Indonesia. International Journal of Islamic and Middle Eastern Finance and Management, 12(5), 643-662.

[OJK] Ototitas Jasa Keuangan. (2020). Snapshot Perbankan Syariah Indonesia 2020. Jakarta (ID), Otoritas Jasa Keuangan.

[OJK] Ototitas Jasa Keuangan. (2020). Statistik Perbankan Syariah Oktober 2020. Jakarta (ID), Otoritas Jasa Keuangan.

Ozkan, S., Kaytmaz, C., Balsari, \& Varan, S. (2014). Effect of banking regulation on performance: Evidence from Turkey. Emerging Markets Finance and Trade, 50(4), 196-221.

Pratama, B. (2010). Analisis faktor-faktor yang mempengaruhi kebijakan penyaluran kredit perbankan (studi pada Bank Umum di Indonesia periode tahun 2005-2009). Jurnal Bisnis Strategi, 19(2), 135-148.

Rajan, R. G. (1994). Why bank credit policies fluctuate: A theory and some evidence. The Quarterly Journal of Economics, 109(2), 399-441.

Rizwan, M. S., Ahmad, G. \& Ashraf, D. (2020). Systemic risk: The impact of covid-19. Finance Research Letters, 1-15.

Saadaoui, Z., \& Hamza, H. (2020). Lending cyclicality in dual banking system: empirical evidence from GCC countries. Journal of Islamic Accounting and Business Research.

Shah, M. R., Rashid, A. \& Hassan, M. K. (2019). On the role of Islamic and conventional banks in the monetary policy transmission in Malaysia: Do bank size and liquidity matter?. Research in International Business and Finance, 1-32.

Shido-Ikwu, B. S. (2017). Economic recession in Nigeria: A case for government intervention. SSRG International Journal of Economics and Management Studies (SSRG-IJEMS), 4(6), 50-53.

Soedarmono, W., Pramono, S. E. \& Tarazi, A. (2017). The procyclicality of loan loss provisions in Islamic banks. Research in International Business and Finance, 39, 911-919. 
Syamlan, Y. T. \& Jannah, W. (2019). The determinant of credit risk in Indonesian Islamic commercial banks. Share: Jurnal Ekonomi dan Keuangan Islam, 8(2), 181-206.

Thiagarajan, D. S. (2018). An analysis of performance of commercial banks in Belize during post global recession period. Journal of Finance and Bank Management, 6(2), 33-47.

Viphindrartin, S., Zainuri \& Anugrah, M. Z. (2020). How Islamic bank managing risk? An emphasis on anticipating financial crisis. Al-Uqud: Journal of Islamic Economics, 4(2), 208-227.

Vozzella, P. \& Gabbi, G. (2020). Banking regulation, procyclicality, and asset correlations in the real economic environment. The European Journal of Finance, 1-16.

Warijoyo, P., \& Solikin. (2003). Monetary Policy in Indonesia, Series Book No 6. Jakarta (ID), Bank Indonesia.

Weill, L. \& Zins, A. (2021). Is Islamic banking more procyclical? Cross-country evidence. Comparative Economic Studies, 63(2), 318-335.

West, K. D. (1990). The sources of fluctuations in aggregate inventories and GNP. Quarterly Journal of Economics, 105, 939-973.

Wulandari, R. (2012). Do credit channel and interest rate channel play important role in monetary transmission mechanism in Indonesia?: A structural vector autoregression model. ProcediaSocial and Behavioral Sciences, 65, 557-563.

Yuanyan, Z. \& Tressel, T. (2017). Effectiveness and channels of macroprudential policies: Lessons from the Euro area. Journal of Financial Regulation and Compliance.

Zaid, Z., Ajid, U. \& Imran, I. (2020). Bank lending procyclicality: A comparative study of conventional and Islamic banks. Accountancy Business and the Public Interest, 254-266.

Zulkhibri, M., \& Sakti, M. P. (2018). Procyclicality and bank lending behavior in Indonesia: The case of dual banking system. Journal of Islamic Monetary Economics and Finance, 4(1), 1-16. 